Ames, B. N., Garry, B. \& Herzenberg, L. A. (1960). J. gen. Microbiol. 22, 369-378

\title{
The Genetic Control of the Enzymes of Histidine Biosynthesis in Salmonella typhimurium
}

\author{
By B. N. AMES, BARBARA GARRY AND \\ LEONORE A. HERZENBERG \\ National Institute of Arthritis and Metabolic Diseases, National \\ Institutes of Health, Bethesda, Maryland, U.S.A.
}

\begin{abstract}
SUMMARY: The last four enzymes in the pathway of L-histidine biosynthesis have been assayed in various histidineless mutants of Salmonella typhimurium. Three classes of mutants (B, C and D) have been shown to be associated with lack of imidazoleglycerol phosphate dehydrase, imidazoleacetol phosphate transaminase, and histidinol dehydrogenase, respectively. These studies, in conjunction with the genetic work of Hartman, Loper \& Serman (1960), indicate that the sequence of the genes on the chromosome corresponds to the sequence of the enzymes in the pathway of the biosynthesis. Certain mutants, which were shown genetically to behave as multisite mutants, have been shown to be missing these three enzymes. These multisite mutants are also missing a fourth biosynthetic enzyme, histidinol phosphate phosphatase, for which no single site mutants are available. It has been found that the level of activity of the series of enzymes of histidine biosynthesis can be raised about 15-fold over the wild-type level by growing a histidine-requiring mutant on formylhistidine as a source of histidine.
\end{abstract}

Biochemical and genetic studies on Neurospora crassa and Escherichia coli have indicated the following pathway of histidine biosynthesis in these organisms :

(1) D-erythro-imidazoleglycerol phosphate (IGP) $\rightarrow$ imidazoleacetol phosphate (IAP) $+\mathrm{H}_{2} \mathrm{O}$;

(2) imidazoleacetol phosphate $+\mathrm{L}$-glutamate $\rightleftharpoons$ L-histidinol phosphate $+\alpha$ ketoglutarate;

(3) L-histidinol phosphate $+\mathrm{H}_{2} \mathrm{O} \rightarrow \mathrm{L}$-histidinol + inorganic phosphate;

(4) L-histidinol $+2 \mathrm{DPN}+\mathrm{H}_{2} \mathrm{O} \rightarrow$ L-histidine $+2 \mathrm{DPNH}+2 \mathrm{H}^{+}$.

Reaction 1 is catalysed by the enzyme IGP dehydrase (Ames 1957b), reaction 2 by the enzyme IAP transaminase (Ames \& Horecker, 1956), and reaction 3 by the enzyme L-histidinol phosphate phosphatase (Ames, 1957a). Reaction 4 is catalysed by the enzyme L-histidinol dehydrogenase (Adams, 1954, 1955).

There appear to be two steps leading to the formation of the imidazole ring (Moyed \& Magasanik, 1957). The first reaction appears to involve the condensation of phosphoribosyl-pyrophosphate (PRPP) with adenylic acid to form an uncharacterized substance called compound III. The second is the conversion of compound III, in the presence of glutamine, to imidazoleglycerol phosphate. Each of these steps is catalysed by a separate enzyme (Moyed \& Magasanik, 1960).

Some of the genes controlling the various histidine-synthesizing enzymes are located on different chromosomes in Neurospora crassa (Haas, Mitchell, 
Ames \& Mitchell, 1952) and are unlinked or very loosely linked in yeast (Leupold, 1958). In Salmonella typhimurium, however, the histidine genes are closely linked (Hartman, 1956). Evidence obtained by Hartman (1956) suggested that the histidine-synthesizing pathway in $S$. typhimurium is the same as in $N$. crassa and that the histidine genes appeared to be linked in the same sequence as the steps in the biosynthetic pathway.

The present study shows that Salmonella typhimurium contains the enzymes catalysing reactions $1,2,3$ and 4 of this enzymic pathway. The different genetic classes of $S$. typhimurium histidine-requiring mutants have been examined for these four enzymes and three of the mutant classes have been correlated with the lack of one of the enzymes. Taken in conjunction with the genetic work on these mutants (Hartman, Loper \& Serman, 1960) the present findings indicate that the sequence of the genes on the chromosome does correspond to the sequence of the enzymes in the biosynthesis. In addition, a correlation of multisite mutations with multiple enzymic defects has been made. The investigation of the mutants to locate enzymic blocks has been facilitated by greatly increased enzyme levels produced by the cells in response to growth on formylhistidine.

\section{METHODS}

Compounds and other materials. Histidinol phosphate and imidazoleglycerol phosphate were synthesized as described previously (Ames \& Horecker, 1956; Ames, 1957 $b$ ). The procedure for the purification of the synthetic IGP has been modified slightly in order to remove an ultraviolet-absorbing impurity. Two mmole of the IGP were chromatographed on a column $(2.5 \mathrm{~cm} . \times 45 \mathrm{~cm}$.) of Dowex $50 \mathrm{~W}-\mathrm{H}^{+}(\times 8,200-400 \mathrm{mesh})$ with a linear gradient of water $(500 \mathrm{ml}$.) up to $0.5 \mathrm{~N}-\mathrm{HCl}(500 \mathrm{ml}$.). The symmetrical peak containing the IGP was pooled, and chromatographed on a column $(2.5 \mathrm{~cm} . \times 45 \mathrm{~cm}$.) of Dowex-1 acetate $(\times 8,200-400$ mesh) to remove the chloride ion. The IGP was eluted from the Dowex-1 with $1 \mathrm{~N}$-acetic acid, pooled, and freeze-dried to give IGP monohydrate as a white powder.

L-Histidinol was a gift of Drs Elijah Adams and Herbert Tabor (Bauer, Adams \& Tabor, 1955). We are grateful to Dr Howard Bond who synthesized the $N$ - $\alpha$-formyl-L-histidine (Fischer \& Cone, 1908). Diaphorase was purchased from Worthington Biochemical Corp., Freehold, N.J., U.S.A. 'Superbrite' glass beads (no. 150,75 $\mu$ ), for use in the Nossal shaker, were purchased from Minnesota Mining and Manufacturing Co., St Paul, Minn., U.S.A.

Medium. The minimal medium used was that of Vogel \& Bonner (1956), supplemented with $1 \mathrm{ml} . / \mathrm{l}$. of trace element solution $\left(\mu \mathrm{g} . / \mathrm{ml} .: \mathrm{CoSO}_{4}, 130\right.$; $\mathrm{H}_{3} \mathrm{BO}_{3}, 290$; ammonium molybdate, $750 ; \mathrm{FeCl}_{3}, 480 ; \mathrm{MnCl}_{2}, 280 ; \mathrm{CuCl}_{2}, 270$; $\mathrm{ZnCl}_{2}, 2000$ ). The carbon source, glucose, was added (as a sterile $50 \%(\mathrm{w} / \mathrm{v}$ ) solution) to the autoclaved medium to give a final concentration of $0.5 \%$.

Growth of strains. Test tubes with $10 \mathrm{ml}$. of minimal medium were inoculated from a slope of the Salmonella typhimurium strain. A supplement of L-histidine was added $(0.2 \mathrm{~mm})$ for growth of the histidine-requiring mutants. The 
tubes were incubated overnight at $37^{\circ}$ with aeration and then refrigerated. These cultures could be used as an inoculum for several weeks.

A $0.5 \mathrm{ml}$. sample of the refrigerated inoculum was added to $200 \mathrm{ml}$. of minimal medium in a $500 \mathrm{ml}$. flask and the flask shaken for $15 \mathrm{hr}$. at $37^{\circ}$ on a New Brunswick Co. rotary shaker. A supplement of L-histidine or formylhistidine $(0.03 \mathrm{~mm})$ was added for the growth of the histidine mutants. A concentration of $0.03 \mathrm{~mm}$-histidine gave approximately half-maximal growth.

The bacterial titres of the cultures were determined turbidometrically, and samples from the grown cultures of mutants were routinely streaked on minimal plates to determine if the number of wild-type organisms in the population was significant.

Extracts. The bacteria were harvested by centrifuging for $10 \mathrm{~min}$. at $8000 \mathrm{~g}$. They were then washed at room temperature with $40 \mathrm{ml}$. of $0.05 \mathrm{M}$-triethanolamine-HCl buffer ( $\mathrm{pH} \mathrm{7.5),} \mathrm{again} \mathrm{centrifuged,} \mathrm{and} \mathrm{resuspended} \mathrm{in} \mathrm{this} \mathrm{buffer}$ to give a volume slightly greater than $1.5 \mathrm{ml}$.

Suspension (1.5 ml.) was put in a chilled Nossal tube (Nossal, 1953) with $0.75 \mathrm{~g}$. glass beads and shaken $1 \mathrm{~min}$. at $0^{\circ}$ on a Nossal shaker. The brokencell extract was transferred to a $15 \mathrm{ml}$. plastic centrifuge tube and centrifuged $20 \mathrm{~min}$. at $25,000 \mathrm{~g}$. The supernatant liquid was then dialysed at $4^{\circ}$ for a total of $2.5 \mathrm{hr}$. against two changes of $1500 \mathrm{ml}$. of $0.01 \mathrm{M}$-triethanolamine$\mathrm{HCl}$ buffer ( $\mathrm{pH} \mathrm{7 \cdot 5}$ ). This dialysed extract usually contained about $3 \mathrm{mg}$. protein $/ \mathrm{ml}$. and was used for all of the assays.

Dehydrase assay. The assay was similar to that described for Neurospora (Ames, 1957 b). IAP, the product of the reaction, was measured by its ultraviolet absorption in alkali. A buffer mixture was made of $5.0 \mathrm{ml} . \mathbf{0} \cdot 1 \mathrm{M}$ triethanolamine- $\mathrm{HCl}(\mathrm{pH} \mathrm{8.0)}, 0.03 \mathrm{ml}$. 2-mercaptoethanol (14.3 M) and $0.01 \mathrm{ml}$. $0.1 \mathrm{M}-\mathrm{MnCl}_{2}$. Each incubation contained $0.30 \mathrm{ml}$. of the buffer mixture, $0.005-0.04 \mathrm{ml}$. of dialysed extract, and $0.02 \mathrm{ml}$. of $0.1 \mathrm{M}$ neutral (KOH) IGP solution. The assay tube was incubated $30 \mathrm{~min}$. at $37^{\circ}$ and then the reaction was stopped with $0 \cdot 7 \mathrm{ml} .1 \cdot 43 \mathrm{~N}-\mathrm{NaOH}$. The tubes were incubated for another $30 \mathrm{~min}$. at $37^{\circ}$, and the optical density read at $290 \mathrm{~m} \mu$ against an incubation blank containing water instead of IGP. A small correction for IGP absorption at $290 \mathrm{~m} \mu$ was necessary with some batches of IGP. With crude extracts proportionality of enzyme concentration to optical density was observed to an optical density of 0.800 . Each $0.01 \mu$ mole of IAP formed in the assay resulted in an optical density increase of 0.051. An enzyme unit is defined as the amount of ensyme catalysing the formation of $1 \mu$ mole of IAP/hr. under the assay conditions.

Transaminase assay. The assay was similar to that previously described for the Neurospora enzyme (Ames \& Horecker, 1956) except that the IAP formed was measured directly by its absorption in alkali rather than by hydrolysing it to imidazole-acetol. Pyridoxal phosphate, though often not stimulatory with the crude extracts, was routinely added to the assay mixture. 8-Hydroxyquinoline and ethylenediaminetetra-acetate were added to inhibit phosphatases which might hydrolyse the histidinol phosphate substrate or IAP product. An $\alpha$-ketoglutarate mixture was prepared before each assay; this mixture 
contained $2.81 \mathrm{ml}$. 0.2 M-triethanolamine-HCl (pH 8.4), $0.06 \mathrm{ml}$. mercaptoethanol, $0.08 \mathrm{ml} .0 \cdot 4 \mathrm{M}-\alpha$-ketoglutarate (neutralized with $\mathrm{KOH}$ to $\mathrm{pH}$ ), $0.15 \mathrm{ml}$. 0.04 M-8-hydroxyquinoline (brought to $\mathrm{pH} 3$ with $\mathrm{HCl}$ ), and $0.90 \mathrm{ml}$. $0 \cdot 1 \mathrm{~m}$-disodium ethylenediaminetetra-acetate. The assay tube contained $0.01-0.04 \mathrm{ml}$. of dialysed extract and buffer to a volume of $0.09 \mathrm{ml}$. and was pre-incubated $5 \mathrm{~min}$. at $25^{\circ}$. The pre-incubation buffer was $0 \cdot 2 \mathrm{M}$-triethanolamine (pH 8.4) which was $60 \mu \mathrm{M}$ in pyridoxal phosphate. After the preincubation, $0.20 \mathrm{ml}$. of the $\alpha$-ketoglutarate mixture was added, and the tube put in a $37^{\circ}$ bath. The reaction was started by the addition of $0.01 \mathrm{ml} .0 .1 \mathrm{M}-$ histidinol phosphate. After $20 \mathrm{~min}$. at $37^{\circ}, 0 \cdot 7 \mathrm{ml} .1 \cdot 43 \mathrm{~N}-\mathrm{NaOH}$ was added to stop the reaction. The tube was incubated $30 \mathrm{~min}$. more at $37^{\circ}$ and then the optical density of the mixture was read at $295 \mathrm{~m} \mu$ against an incubation blank containing water instead of the histidinol phosphate. With crude extracts the assay showed proportionality of enzyme concentration to optical density up to an optical density of $0 \cdot 250$. Each $0.01 \mu$ mole of IAP formed in the assay resulted in an optical density increase of 0.080. A unit of enzyme activity is defined as the amount of enzyme catalysing the formation of $1 \mu$ mole of IAP/ hr. under the assay conditions.

Phosphatase assay. The assay requirements were similar to those described for the Neurospora enzyme (Ames, 1957a) except that a $\mathrm{pH} \mathrm{7.5} \mathrm{buffer} \mathrm{was}$ used, as this is the pH optimum for the Salmonella typhimurium enzyme as contrasted with a $\mathrm{pH} 9 \cdot 0$ optimum for Neurospora crassa. The incubation mixture consisted of $0 \cdot 005-0.02 \mathrm{ml}$. dialysed enzyme, $0.01 \mathrm{ml}$. 0.1 M-histidinol phosphate and $0.1 \mathrm{M}$-triethanolamine- $\mathrm{HCl}(\mathrm{pH} \mathrm{7.5)}$ to give a volume of $0.3 \mathrm{ml}$. The mixture was incubated at $37^{\circ}$ for $30 \mathrm{~min}$. when the reaction was stopped with $0.7 \mathrm{ml}$. of ascorbic acid + molybdate reagent. This reagent was used for the determination of inorganic phosphate and consisted of 1 part of $10 \%(\mathrm{w} / \mathrm{v})$ ascorbic acid and 6 parts of $0.42 \%(\mathrm{w} / \mathrm{v})$ ammonium molybdate. $4 \mathrm{H}_{2} \mathrm{O}$ in $1 \mathrm{~N}-\mathrm{H}_{2} \mathrm{SO}_{4}$ (Chen, Toribara \& Warner, 1956). The tubes were then kept for $20 \mathrm{~min}$. at $45^{\circ}$ and read at $820 \mathrm{~m} \mu$ against an enzyme + buffer blank without histidinol phosphate. A small correction may be necessary when a trace of inorganic phosphate is present in the histidinol phosphate.

Deproteinization usually was not necessary in the assay as little enzyme was used because of the sensitivity of the phosphate determination. When enough protein was present to cause a precipitation, however, the phosphate adsorbed to the precipitate and a low reading resulted. Each $0.01 \mu$ mole of inorganic phosphate formed in the assay resulted in an optical density increase of $0 \cdot 260$. A unit of enzyme activity is defined as that amount of enzyme which liberates $1 \mu$ mole of inorganic phosphate/hr. under the assay conditions.

Histidinol dehydrogenase assay. The assay was similar to that described for the Escherichia coli enzyme (Adams, 1954). Diaphorase catalysed the reduction of dichlorophenolindophenol dye by the DPNH formed in the oxidation of histidinol. The assay was done in a Cary spectrophotometer at $25^{\circ}$ by measuring the disappearance of the blue colour of the dye at $600 \mathrm{~m} \mu$. A buffer + dye mixture contained 5 parts of $0.4 \mathrm{~mm}$ dye solution and 4 parts of 0.2 $\mathrm{M}$-triethanolamine-HCl buffer, $\mathrm{pH} 8 \cdot 4$. Each curvette contained dialysed 
enzyme (0.01-0.05 ml.), 0.9 ml. buffer + dye mixture, $0.05 \mathrm{ml}$. 0.05 M-DPN solution ( $\mathrm{pH} 5$ with $\mathrm{KOH}$ ) and an excess of diaphorase $(0.01 \mathrm{ml}$. of Worthington product, $4 \mathrm{mg} / \mathrm{ml}$.). After the small endogenous oxidation ended and the dye was not reduced further $0.02 \mathrm{ml}$. of $0.1 \mathrm{M}$-histidinol solution $(\mathrm{pH} \mathrm{r}$, $\mathrm{NaOH}$ ) was added and the rate of dye bleaching determined. With the crude extracts the assay showed proportionality of enzyme concentration to the rate of dye reduction up to a rate of 0.080 optical density units per min. A decrease in optical density of $0 \cdot 6$ was equal to $0.01 \mu$ mole histidinol oxidized. One unit of enzyme activity is defined as the quantity of enzyme required for oxidation of $1 \mu$ mole of histidinol per hr. under the assay conditions.

Protein determination. The specific activities of the various enzymes are expressed as units per mg. protein. Protein was determined by the Folin method (Lowry, Rosebrough, Farr \& Randall, 1951) with zinc insulin as a standard. Triethanolamine buffer, against which the enzyme extracts were dialysed, interfered in the protein determination. This interference was corrected for by using an insulin standard curve determined in the presence of the amount of buffer present in the aliquot of dialysed extract taken for a protein determination (see Ames \& Garry, 1959, footnote 18).

\section{RESULTS}

Effect of formylhistidine on enzyme levels. The size of the pool of histidine in the bacterial cell appears to regulate the rate of synthesis of the histidine biosynthetic enzymes (see Discussion). Various methods have been investigated for limiting the size of this histidine pool in order to obtain higher concentrations of the biosynthetic enzymes in the cell, thereby facilitating the experimental association of the various histidine-requiring mutants with a lack of a particular biosynthetic enzyme. A simple method for limiting the availability of histidine in the cell during the entire growth period, and thus increasing the enzyme concentration, was realized by growing the histidinerequiring mutants on a derivative of histidine as a source of histidine. One such derivative, $\mathrm{N}$ - $\alpha$-formyl-L-histidine, when used as a source of histidine for the mutants, resulted in very high concentrations of the enzymes. The enzyme activity in the wild-type, and in various mutants grown on excess histidine or on formylhistidine, is given in Table 1 which shows that the various mutants had the low wild-type concentrations of enzymes when grown on excess histidine, but a high concentration of enzymes when grown on formylhistidine. Neither histidine nor formylhistidine had any effect on the enzyme concentrations in the wild-type.

The doubling time for growth of the histidine-requiring mutants on $0.03 \mathrm{~mm}$-formylhistidine was about $100 \mathrm{~min}$., as compared to a doubling time of $38 \mathrm{~min}$. on histidine $(0.01-1.0 \mathrm{~mm})$. The wild-type had a doubling time of $38 \mathrm{~min}$. with or without supplements. The long doubling time of the formylhistidine-grown cells might be a result of the slow hydrolysis of formylhistidine to histidine.

Enzyme levels in the various histidine mutants. The different histidine mutants were grown in minimal medium (0.03 $\mathrm{mm}$ in formylhistidine), and assayed for 
the four enzymes (see Methods). The results are given in Table 2 which shows that mutants from the genetic classes $E, F, A, H$, and $G$ contained all four enzymes while $B$ mutants lacked the dehydrase, $C$ mutants the transaminase and $D$ mutants the dehydrogenase. The mutants his-F AHBCD152 and his-57 which, genetically, were shown to cover many histidine genes (Hartman, Loper \& Serman, 1960) contained none of the enzymes. The mutants hisB-22, hisG-203 and $h i s G D-63$ are of interest in that, although genetically they behave

\section{Table 1. The specific activity of four of the enzymes of histidine biosynthesis} in Salmonella typhimurium grown on histidine or formylhistidine

The specific activity for each of the enzymes is expressed as enzyme units/mg. protein. The conditions for growth and enzyme assay are described under Methods.

\begin{tabular}{|c|c|c|c|c|c|c|}
\hline \multirow[t]{2}{*}{ Mutant } & \multirow[t]{2}{*}{ Enzymic block } & \multirow[t]{2}{*}{ Supplement } & $\begin{array}{l}\text { Dehy- } \\
\text { drase }\end{array}$ & $\begin{array}{l}\text { Trans- } \\
\text { aminase }\end{array}$ & $\begin{array}{l}\text { Phos- } \\
\text { phatase }\end{array}$ & $\begin{array}{c}\text { Dehydro } \\
\text { genase }\end{array}$ \\
\hline & & & \multicolumn{4}{|c|}{$\begin{array}{l}\text { arase aminase phatase genase } \\
\text { (enzyme units/mg./protein) }\end{array}$} \\
\hline Wild-type & - & None & 0.58 & 0.91 & $\mathbf{1 \cdot 3}$ & $0 \cdot 13$ \\
\hline Wild-type & - & $1.0 \mathrm{~mm}$ histidine & 0.65 & 0.94 & $1 \cdot 4$ & 0.06 \\
\hline Wild-type & - & $0.03 \mathrm{~mm}$-formylhistidine & 0.54 & $0 \cdot 73$ & $1 \cdot 1$ & $0 \cdot 12$ \\
\hline$E 11$ & Unknown & $1.0 \mathrm{~mm}$ histidine & $\mathbf{0 . 3 5}$ & 0.68 & $1 \cdot 0$ & 0.08 \\
\hline$E 11$ & Unknown & $0.03 \mathrm{~mm}$ formylhistidine & $\mathbf{3 \cdot 0}$ & $14 \cdot 4$ & $14 \cdot 4$ & $2 \cdot 1$ \\
\hline G52 & Unknown & l.0 $\mathrm{mm}$ histidine & 0.55 & $\mathbf{0} \cdot 78$ & $1 \cdot 1$ & 0.04 \\
\hline G52 & Unknown & $0.03 \mathrm{~mm}$ formylhistidine & $4 \cdot 9$ & $17 \cdot 1$ & $15 \cdot 4$ & $\mathbf{1} \cdot \mathbf{9}$ \\
\hline$B 40$ & Dehydrase & $1.0 \mathrm{~mm}$ histidine & $<0.04$ & $\mathbf{0 . 6 9}$ & $\mathbf{0 . 3 5}$ & 0.02 \\
\hline$B 40$ & Dehydrase & $0.03 \mathrm{~mm}$ formylhistidine & $<0.06$ & $16 \cdot 9$ & $14 \cdot 6$ & $\mathbf{2 \cdot 2}$ \\
\hline Da10 & Dehydrogenase & $1.0 \mathrm{~mm}$ histidine & $\mathbf{0 . 8 9}$ & 0.94 & $\mathbf{0 . 8 1}$ & $<0.01$ \\
\hline Da10 & Dehydrogenase & $0.03 \mathrm{~mm}$ formylhistidine & - & $12 \cdot 9$ & $19 \cdot 4$ & $<0.01$ \\
\hline
\end{tabular}

Table 2. Specific activities of histidine biosynthetic enzymes in various mutant strains of Salmonella typhimurium grown on formylhistidine

\begin{tabular}{|c|c|c|c|c|c|}
\hline \multirow[t]{2}{*}{ Mutant } & \multirow[t]{2}{*}{ Enzymic block } & \multirow{2}{*}{$\begin{array}{r}\text { Dehydrase } \\
\text { (specific }\end{array}$} & $\begin{array}{l}\text { Trans- } \\
\text { aminase }\end{array}$ & Phosphatase & \multirow{2}{*}{$\begin{array}{c}\text { Dehydro } \\
\text { genase } \\
\text { protein) }\end{array}$} \\
\hline & & & ctivity enz & me units/mg. & \\
\hline$E 11$ & Unknown & 8.0 & $14 \cdot 4$ & $14 \cdot 4$ & $2 \cdot 1$ \\
\hline$E 35$ & Unknown & $\mathbf{2} \cdot \mathbf{5}$ & $6 \cdot 6$ & $12 \cdot 7$ & $1 \cdot 4$ \\
\hline EF 135 & $($ PRPP $\rightarrow$ III $)$ & $2 \cdot 2$ & $11 \cdot 0$ & 9.7 & $1 \cdot 6$ \\
\hline$F A 55$ & $($ PRPP $\rightarrow$ III $)$ & $1 \cdot 1$ & $\mathbf{2} \cdot 0$ & 4.9 & $0 \cdot 60$ \\
\hline$F 41$ & $(\mathbf{P R P P} \rightarrow$ III $)$ & $1 \cdot 7$ & $3 \cdot 6$ & $8 \cdot 6$ & 0.01 \\
\hline$A H 134$ & $(\mathrm{III} \rightarrow \mathrm{IGP})$ & $1 \cdot 1$ & $2 \cdot 5$ & $5 \cdot 3$ & 0.54 \\
\hline$A 3$ & $($ III $\rightarrow$ IGP) & 0.88 & $2 \cdot 6$ & $6 \cdot 0$ & 0.61 \\
\hline $\mathrm{H} 32$ & $($ III $\rightarrow$ IGP) & 0.49 & $2 \cdot 0$ & $2 \cdot 9$ & 0.32 \\
\hline$B 40$ & Dehydrase & $<0.05$ & $16 \cdot 2$ & $12 \cdot 3$ & $\mathbf{3} \cdot \mathbf{2}$ \\
\hline B22 & Dehydrase & $<0.04$ & $0 \cdot 26$ & 0.60 & $1 \cdot 0$ \\
\hline$C 201$ & Transaminase & $\mathbf{3 . 5}$ & $<0.01$ & $16 \cdot 6$ & 0.81 \\
\hline Da10 & Dehydrogenase & - & $12 \cdot 9$ & $19 \cdot 4$ & $<0.02$ \\
\hline$D b 1$ & Dehydrogenase & 1.7 & $8 \cdot 2$ & $5 \cdot 8$ & $<0.04$ \\
\hline G52 & Unknown & $4 \cdot 9$ & $17 \cdot 1$ & $15 \cdot 4$ & $1 \cdot \boldsymbol{\theta}$ \\
\hline G203 & Multiple & $<0.14$ & $<0.16$ & $<0.06$ & $<0.04$ \\
\hline GD63 & Multiple & $\mathbf{0 . 2 3}$ & $<0.03$ & 0.35 & $<0.04$ \\
\hline$F A H B C D 152$ & Multiple & $<0.05$ & $<0.01$ & $<0.07$ & $<0.04$ \\
\hline 57 & Multiple & $<0.07$ & $<0.03$ & $<0.01$ & $<0.04$ \\
\hline
\end{tabular}


as multisite mutants restricted to the $B, G$, and $G D$ loci respectively (Hartman, Loper \& Serman, 1960), the function of neighbouring genes seems impaired, i.e. his $B$ - 22 has extremely low transaminase and phosphatase activity in addition to the lack of dehydrase.

At least three separate mutants from each mutant class have been analysed after growth on both histidine and formylhistidine. Since the results from mutants comprising single genetic classes are consistent, only the data where all four enzymes have been analysed in the same extract have been presented.

Although inhibitory substances were looked for by adding extracts from mutants lacking a particular enzyme to an active enzyme preparation, no evidence for such substances was found.

In the extracts of mutants where all four enzymes were missing, it was thought desirable to show some sort of enzymic activity, as a control. The glutamic dehydrogenase activity in these mutants was determined and shown to be of the same degree as in the other mutants.

Mixing of dehydrogenase extracts. The histidinol dehydrogenase gene (D class) was found to consist of two parts ( $D a$ and $D b)$; mutants for each part were found to complement each other genetically (Hartman, Hartman \& Serman, 1960). Extracts from the formylhistidine-grown complementing strains $h i s D a-10$ and $h i s D b-1$ were mixed, but no detectable enzyme activity was found under the conditions of the assay.

\section{DISCUSSION}

The accompanying papers (Hartman, Loper \& Šerman, 1960; Hartman, Hartman \& Serman, 1960) present genetic evidence for the grouping of several hundred histidine-requiring mutants into representatives of seven gene loci. Each of these genes was assigned a letter of the alphabet. These seven loci were closely linked and linearly arranged in the order $E, F, A, B, C, D, G$. Another class, $H$, may be part of the $A$ class.

The present study of the various mutants with respect to the enzymes of histidine biosynthesis shows that mutants in the $B$ class lack IGP dehydrase, mutants in the $C$ class lack IAP transaminase, and mutants in the $D$ class lack histidinol dehydrogenase. Mutants in all the other classes possess the last four enzymes of the pathway. Moyed \& Magasanik (1960; personal communication) have stated that mutant hisF-41 contains less than $5 \%$ of the normal amount of the first enzyme of the pathway (the enzyme which catalyses the reaction PRPP $\rightarrow$ III and that the second enzyme, which catalyses the reaction III $\rightarrow$ IGP, cannot be detected in mutant his $A-5$. These results, in conjunction with our data, indicate that the sequence of the genes $F, A$, $B, C, D$ in the linkage map (Hartman, Loper \& Serman, 1960) corresponds to the sequence of the enzymes which they control in the biosynthetic pathway. The functions of the $E$ and $G$ genes, which are mapped at the two ends of the gene sequence, are unclear; mutants in these classes contain all of the enzymes that were assayed. Possible functions for these genes include control of a 
matrix protein, or control of a histidine-activating enzyme (mutants may have an altered Michaelis constant).

Certain mutants such as hisFAHBCD-152 seem to be damaged over a long length of the chromosome. Genetically, mutant hisFAHBCD-152 lacks genes $F, A, B, C$ and $D$ (Hartman, Loper \& Serman, 1960), and biochemically it lacks all four of the histidine enzymes examined. Although no mutants are available which lack only the phosphatase, the fact that multisite mutants such as hisF AHBCD-152 have less than $1 \%$ of the expected phosphatase activity suggests that this gene is linked to the other genes concerned in histidine biosynthesis.

The absence of Salmonella typhimurium mutants lacking only the phosphatase may be explained by analogy with a similar case in Neurospora. Of several hundred histidine-requiring Neurospora mutants isolated (Haas et al. 1952 ; B. Webber and N. Giles, personal communication;Mathieson \& Catcheside, 1955), only one phosphatase mutant has been identified. This mutant lacks the specific histidinol phosphate phosphatase but shows non-specific phosphatase activity toward histidinol phosphate (Ames, 1957a). This mutant is quite 'leaky' (i.e. it can grow to some extent on minimal medium) presumably because of this non-specific phosphatase, and most mutants like it are probably overlooked in mutant isolation. So far, non-specific phosphatases have not been specifically looked for in $S$. typhimurium. The lack of any phosphatase activity in some of the multisite mutants suggests that, at $\mathrm{pH} 7 \cdot 5$, the non-specific phosphatase activity is less than 5-10\% of the wild-type specific phosphatase activity. A $5 \%$ value, however, while it could not be detected, might well cause a mutant to be leaky, and to be killed by penicillin during mutant isolation.

The data presented here and in a more detailed study (Ames \& Garry, 1959) indicate that the ratio of one enzyme activity to another is fairly constant over a wide range of specific activities. One striking exception to this constant ratio is the very low transaminase and phosphatase activity in an extract of the multisite dehydrase mutant hisB-22. These low activities are presumably due to some inhibitory effect of the multisite mutation on the expression of neighbouring genes. These observations of low transaminase and phosphatase activity agree with the data on complementation obtained for this mutant (Hartman, Hartman, \& Serman, 1960). A similar effect on the expression of nearby genes is noted for the multisite mutants hisG-203 and hisGD-63. However, this is not universally true of multisite mutants since his $A H-134$, and $h i s F-41$ do not show this behaviour, although $A H-134$ is near the dehydrase locus and some inhibitory effect would be seen if it were present.

During the initial studies histidine mutants were routinely grown on histidine and could be placed in different classes. But because of the limitations of the assays, a mutant lacking a particular enzyme could only be said to have less than $10 \%$ of the wild-type value of the enzyme being assayed. Organisms grown on formylhistidine have all the enzyme activities raised to high degree, so that it is possible to determine whether a mutant for a particular enzyme has less than a few per cent of the high degree of enzyme activity. 
Repression of the synthesis of amino acid biosynthetic enzymes by the amino acid end-product has been reported by many investigators (see Vogel, 1957). It also seems as if the amount of histidine normally present in the wild type maximally represses the synthesis of the series of histidine-biosynthesis enzymes (Ames \& Garry, 1959). Gorini \& Maas (1957) obtained much higher than normal values for an arginine biosynthesizing enzyme in an argininerequiring mutant. The rate of growth of the mutant in a chemostat (Novick \& Szilard, 1950) was limited by the rate of arginine addition to the organisms. By growing the histidine mutants on formylhistidine, so that histidine deficiency limits the growth rate, a 'chemical chemostat' has been devised. The increased biosynthetic enzyme values in mutants grown in this way appear to be the result of relieving this histidine repression.

We wish to thank Dr P. E. Hartman for supplying all of the Salmonella typhimurium mutants and for helpful discussion.

\section{REFERENCES}

Adams, E. (1954). The enzymatic synthesis of histidine from histidinol. $J$. biol. Chem. 209, 829.

Adams, E. (1955). L-Histidinol, a biosynthetic precursor of histidine. J. biol. Chem. 217, 325.

Ames, B. N. (1957a). The biosynthesis of histidine: L-histidinol phosphate phosphatase. J. biol. Chem. 226, 583.

Ames, B. N. $(1957 b)$. The biosynthesis of histidine: D-erythro-imidazoleglycerol phosphate dehydrase. J. biol. Chem. 228, 131.

Ames, B. N. \& Horecker, B. L. (1956). The biosynthesis of histidine: Imidazolacetol phosphate transaminase. J. biol. Chem. 220, 113.

Ames, B. N. \& Garry, B. (1959). Coordinate repression of the synthesis of four histidine biosynthetic enzymes by histidine. Proc. nat. Acad. Sci., Wash. 45, 1453.

Bauer, H., Adams, E. \& Tabor, H. (1955). L-Histidinol dihydrochloride. Biochem. Prep. 4, 46.

Chen, P. S., Toribara, T. Y. \& Warner, H. (1956). Microdetermination of phosphorus. Analyt. Chem. 28, 1786.

Fischer, E. \& Cone, L. H. (1908). Derivate des Histidins. Annalen, 363, 116.

Gorini, L. \& MAAs, W. K. (1957). The potential for the formation of a biosynthetic enzyme in E. coli. Biochim. biophys. Acta, 25, 208.

HaAs, F., Mitchell, M. B., Ames, B. N. \& Mitchell, H. K. (1952). A series of histidineless mutants of Neurospora crassa. Genetics, 37, 217.

Hartman, P. E. (1956). Linked loci in the control of consecutive steps in the primary pathway of histidine synthesis in Salmonella typhimurium. In Genetic Studies rwith Bacteria. Publ. Carneg. Instn, no. 612. p. 35.

Hartman, P. E., Hartan, Z. \& Šerman, D. (1960). Complementation-mapping by abortive transduction of histidine-requiring Salmonella mutants. J. gen. Microbiol. 22, 354.

Hartman, P. E., Loper, J. C. \& Šrman, D. (1960). Fine structure mapping by complete transduction between histidine-requiring Salmonella mutants. J.gen. Microbiol. 22, 323.

LeUPOLD, U. (1958). Studies on recombination in Schizosaccharomyces pombe. Cold Spr. Harb. Symp. quant. Biol. 23, 161.

Lowry, O. H., Rosebrough, N. J., Farr, A. L. \& Randall, R. J. (1951). Protein measurement with the Folin phenol reagent. J. biol. Chem. 193, 265. 
Mathieson, M. J. \& Catcheside, D. G. (1955). Inhibition of histidine uptake in Neurospora crassa. J. gen. Microbiol. 13, 72.

Moyed, H. S. (1958). Biosynthesis of the imidazole ring of histidine. Fed. Proc. 17, 279 (abstract).

Moyed, H. S. \& Magasanik, B. (1957). The role of purines in histidine biosynthesis. J. Amer. chem. Soc. 79, 4812.

Moyed, H. S. \& MAGasanik, B. (1960). The biosynthesis of the imidazole ring of histidine. J. biol. Chem. $235,149$.

Nossal, P. M. (1953). A mechanical cell disintegrator. Aust. J. exp. Biol. med. Sci. $31,583$.

Novick, A. \& Szilard, L. (1950). Description of the chemostat. Science, 112, 715.

VoGEL, H. J. (1957). Repression and induction as control mechanisms of enzyme biogenesis: The 'adaptive' formation of acetylornithinase. In The Chemical Basis of Heredity, p. 276. Baltimore: The Johns Hopkins Press.

Vogel, H. J. \& Bonner, D. M. (1956). Acetylornithinase of E. coli. J. biol. Chem. $218,97$. 